\title{
WINTER 2013
}

\section{The}

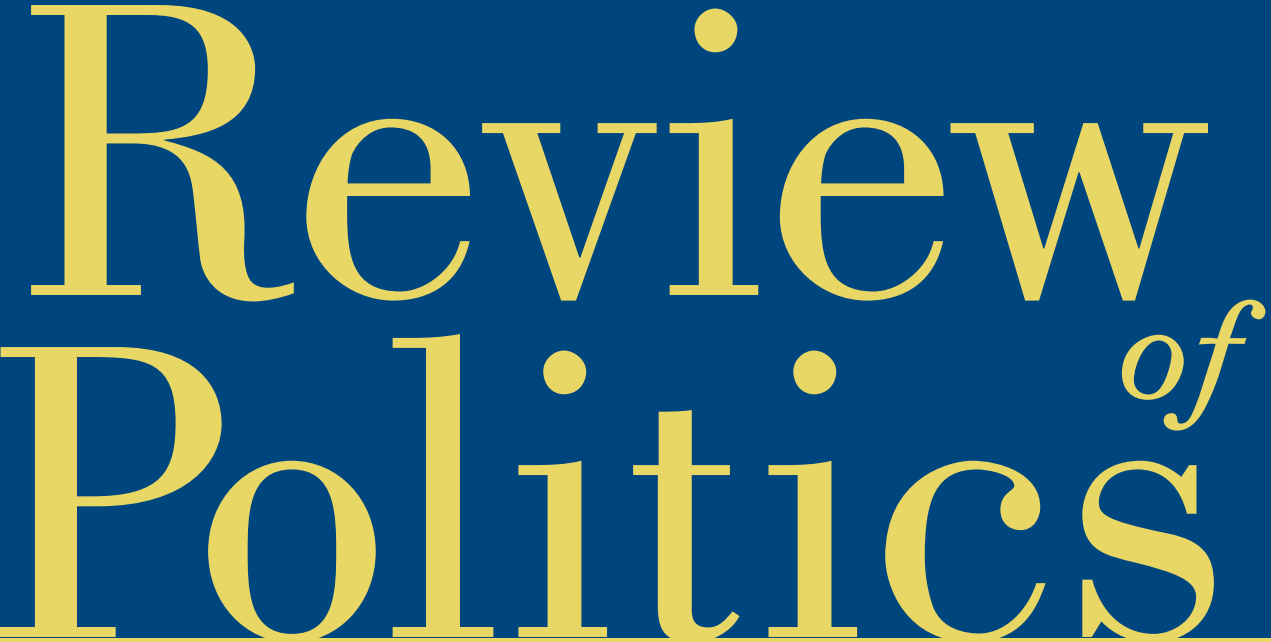

ARTICLES

Christian R. Donath, "Liberal Art: Art and Education for Citizenship in Kant's Critique of Judgment"

Thierry Gontier, "From 'Political Theology' to 'Political Religion': Eric Voegelin and Carl Schmitt"

Luke Philip Plotica, "This Is Simply What I Do': Wittgenstein and Oakeshott on the Practices of Individual Agency"

Alex Zakaras, "A Liberal Pluralism: Isaiah Berlin and John Stuart Mill," with responses by William Galston and George Crowder 


\title{
THE REVIEW OF POLITICS
}

\author{
Editor \\ CATHERINE H. ZUCKERT \\ Executive Associate Editor \\ DENNIS WM MORAN \\ Book Review Editor \\ PETER R. MOODY, JR.
}

Editorial Board

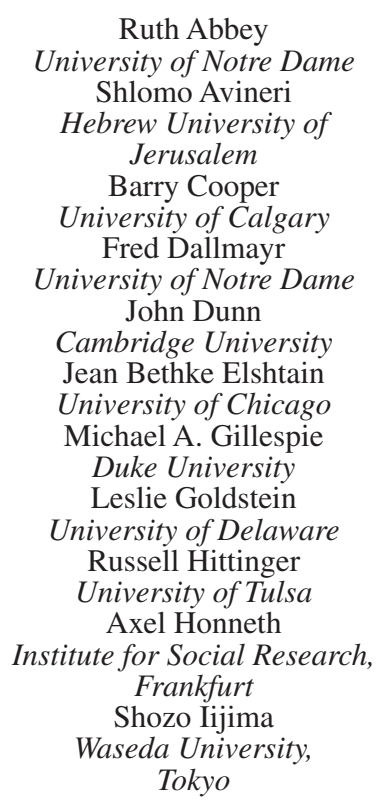

\author{
Ramin Jahanbegloo \\ University of Toronto \\ Pierre Manent \\ L'Ecole des Hautes Etudes en \\ sciences sociales \\ Harvey C. Mansfield \\ Harvard University \\ Mary Nichols \\ Baylor University \\ Daniel Philpott \\ University of Notre Dame \\ Arlene Saxonhouse \\ University of Michigan \\ William E. Scheuerman \\ Indiana University, Bloomington \\ Steven B. Smith \\ Yale University \\ Peter Steinberger \\ Reed College \\ Vickie Sullivan \\ Tufts University \\ Jean M. Yarbrough \\ Bowdoin College
}

\section{Copyeditor: LES HARRIS}

Editorial Interns: Nathan Sawatzky, Madeline Cronin Administrative Assistant: Kelli Brown

\section{Former Editors}

\begin{abstract}
Waldemar Gurian
M.A. Fitzsimons

Thomas Stritch
\end{abstract}

\author{
Frederick J. Crosson \\ Donald P. Kommers \\ Walter Nicgorski
}

The Review of Politics publishes primarily philosophical and historical studies of politics, especially those in political theory and American political thought. The journal also includes thoughtful scholarly reflections on all aspects of politics-laws, and institutions, international relations, comparative politics-as well as literary reflections on politics or political interpretations of literature. 


\section{TABLE OF CONTENTS WINTER 2013}

Vol. 75

WINTER 2013

No. 1

Edward A. Goerner: In Memoriam $\ldots \ldots \ldots \ldots \ldots \ldots \ldots \ldots$

Christian R. Donath

Liberal Art: Art and Education for Citizenship in

Kant's Critique of Judgment . . . . . . . . . . . . . . . 3

Thierry Gontier

From "Political Theology" to "Political Religion":

Eric Voegelin and Carl Schmitt . . . . . . . . . . . 25

Luke Philip Plotica

"This Is Simply What I Do": Wittgenstein and

Oakeshott on the Practices of Individual Agency . . . . . . . 45

Alex Zakaras

A Liberal Pluralism: Isaiah Berlin and John Stuart Mill . . . 69

Responses to Zakaras:

William Galston

Between Logic and Psychology: The Links between Value

Pluralism and Liberal Theory . . . . . . . . . . . 97

George Crowder

Justification and Psychology in Liberal Pluralism:

A Reply to Zakaras . . . . . . . . . . . . . . . . . . 103

Alex Zakaras

Reply to Galston and Crowder . . . . . . . . . . . . . 111

Reviews:

David Tkach: THE POLITICAL DEFENSE OF LIBERTY

Review of David William Bates's States of War: Enlightenment

Origins of the Political . . . . . . . . . . . . . . . . . . 115

Mark A. Graber: THE INTRINSIC VALUE OF LIBERTY

Review of John Tomasi's Free Market Fairness . . . . . . . . . . . . . . 118

Katy J. Harriger: SUCCESSFUL STRATEGY, NOT FAILED

COUNTERREVOLUTION

Review of Kevin J. McMahon's Nixon's Court: His Challenge to Judicial

Liberalism and Its Political Consequences. . . . . . . . . . . . . . 121 
Stewart Winger: STATE POWER AND CIVIL WAR CONSTITUTIONALISM

Review of Mark E. Neely Jr.'s Lincoln and the Triumph of the Nation:

Constitutional Conflict in the American Civil War . . . . . . . . . . . 123

Houston A. Baker Jr.: MACHO MEN

Review of Erica R. Edwards's Charisma and the Fictions of

Black Leadership . . . . . . . . . . . . . . . . . . . . . . . . . . . . . . 128

Bonnie Honig: A SORT OF SECULAR RELIGION

Review of Robert C. Pirro's The Politics of Tragedy and Democratic

Citizenship . . . . . . . . . . . . . . . . . . . . . . . . . . . 132

Mark L. Haas: WHAT NOW?

Review of Charles Lemert's Why Niebuhr Matters . . . . . . . . . . . . . 135

Alissa Jones Nelson: LOVE, OBEDIENCE, AND AUTHORITY

Review of Robert A. Burt's In the Whirlwind: God and Humanity in

Conflict. . . . . . . . . . . . . . . . . . . . . . . . . . . . . . . 138

Emile Lester: ACCOMMODATING RELIGION

Review of Russell Blackford's Freedom of Religion and the

Secular State. .

Johann P. Arnason: THE ARCHAIC AND THE AXIAL

Review of Robert Bellah's Religion in Human Evolution: From the

Paleolithic to the Axial Age . . . . . . . . . . . . . . . . . . 143

Lawrence Ziring: ISLAMISM AS A CONSTRUCTIVE POWER

Review of Nathan J. Brown's When Victory Is Not an Option: Islamist

Movements in Arab Politics. . . . . . . . . . . . . . . . . . . . . . . 149

Robert S. Snyder: WHAT IF

Review of Frank P. Harvey's Explaining the Iraq War: Counterfactural

Theory, Logic and Evidence . . . . . . . . . . . . . . . . . . . . . . 152

Lawrence J. Korb: BIASED CRITIQUE OF THE BIASED

Review of Stephen F. Knott's Rush to Judgment: George W. Bush, the War on

Terror, and His Critics. . . . . . . . . . . . . . . . . . . . . . 155

Stephen Wrage: A DIALECTICALLY CONSTRUCTIVE RELATIONSHIP

Review of Donald Alexander Downs and Ilia Murtazashvili's Arms and the University: Military Presence and the Civic Education of Non-military Students . . . . . . . . . . . . . . . . . . . . . . . . 158

Jeffrey H. Michaels: UNCLEAR FOCUS

Review of Ned O'Gorman's Spirits of the Cold War: Contesting

Worldviews in the Classical Age of American Security Strategy . . . . . . 161

Seán Molloy: NO CRUSADES

Review of Louis B. Zimmer's The Vietnam War Debate: Hans J. Morgenthau and the Attempt to Halt the Drift into Disaster . . . . . . . . . . 163

Anastassia Obydenkova: AUTOCRACY AND THE PEOPLE

Review of Richard Rose, William Mishler, and Neil Munro's Popular

Support for an Undemocratic Regime: The Changing Views of

Russians . . . . . . . . . . . . . . . . . . . . . . . . . . . . . 166

Phil Edwards: FALSE FAITH, FALSE CRITIQUE

Review of Alessandro Orsini's Anatomy of the Red Brigades: The Religious Mind-Set of Modern Terrorists. . . . . . . . . . . . . . . . . 168 
Subscription Information: The Review of Politics (ISSN 0034-6705) is published quarterly in February, May, August and November by Cambridge University Press, 32 Avenue of the Americas, New York, NY 10013-2473 USA/The Edinburgh Building, Shaftesbury Road, Cambridge CB2 8RU, UK for the University of Notre Dame. Annual subscription rates for Volume 75 (2013): Institutional subscription rates, print and online: US $\$ 150.00$ in the USA, Canada, and Mexico; UK $£ 87.00+$ VAT elsewhere. Institutional subscription rates, online only: US $\$ 130.00$ in the USA, Canada, and Mexico; UK $£ 75.00$ + VAT elsewhere. Institutional subscription rates, print only: US $\$ 147.00$ in the USA, Canada, and Mexico; UK $£ 85.00$ + VAT elsewhere. Individual subscription rates, print only: US $\$ 44.00$ in the USA, Canada, and Mexico; UK $£ 25.00$ + VAT elsewhere. Correspondence concerning subscriptions should be sent to: Cambridge University Press, 100 Brook Hill Drive, West Nyack, NY 10994, USA for customers in the USA, Canada, or Mexico. Customers elsewhere should contact: Cambridge University Press, The Edinburgh Building, Shaftesbury Road, Cambridge CB2 8RU, UK.

Editorial Office: All correspondence concerning submissions and manuscripts under review should be sent to The Review of Politics, University of Notre Dame, 547 Flanner Hall, Notre Dame, IN 46556. Phone: 574-631-6623. Email: ROP.Editor.1@nd.edu. Website: www.nd.edu/ rop

Abstracting and Indexing Information: Articles in The Review of Politics are indexed in the International Index to Periodicals and the Catholic Periodicals and Literature Index; abstracted in the International Political Science Abstracts; and abstracted and indexed in ABC POL. SCI., Historical Abstracts, Social Science Index (also available in the electronic versions), Book Review Index, and International Bibliography of the Social Sciences.

Copyright (C) 2013 University of Notre Dame. All rights reserved. No part of this publication may be reproduced, in any form or by any means, electronic, photocopy, or otherwise, without permission in writing from Cambridge University Press, Rights and Permissions Manager, 32 Avenue of the Americas, New York, NY 10013-2473 USA. For further information see http://us.cambridge/org/information/rights/

Periodicals postage paid in New York, NY and additional mailing offices. Postmaster: Send address changes to The Review of Politics, Cambridge University Press, 100 Brook Hill Drive, West Nyack, NY 10994-2133 USA.

Photocopying information for users in the U.S.A.: the Item-Fee Code for the publication (0034-6705/13\$9.00+.10) indicates that copying for internal or personal use beyond that permitted by Sec. 107 or 108 of the U.S. Copyright Law is authorized for users duly registered with the Copyright Clearance Center (CCC) provided that the appropriate remittance of $\$ 9.00$ per article is paid directly to CCC, 222 Rosewood Drive, Danvers, MA 01923. Specific written permission must be obtained for all other copying. 